\title{
Superior Infratentorial Cistern
}

National Cancer Institute

\section{Source}

National Cancer Institute. Superior Infratentorial Cistern. NCI Thesaurus. Code C33679.

A superior infratentorial subarachnoid cistern. 